\title{
БIOXIMIЯ
}

УДК: [561.263+577.115.7] 57.053

doi: $10.25128 / 2078-2357.20 .3-4.7$

\author{
О. І. БОДНАР, Г. Б. КОВАЛЬСЬКА, О. Я. ЛУКАШІВ, В. В. ГРУБІНКО
}

Тернопільський національний педагогічний університет імені Володимира Гнатюка

вул. М. Кривоноса, 2, Тернопіль, 46027

e-mail: bodnar@chem-bio.com.ua

\section{ОЦІНКА БІОЛОГІЧНОЇ ДІЇ ЕЛЕМЕНТВМІСНИХ ЛІПІДНИХ КОМПЛЕКСІВ 3 CHLORELLA VULGARIS НА ФУНКЦІОНАЛЬНИЙ СТАН ЗДОРОВИХ ЩУРІВ}

Хлорела - один 3 найперспективніших видів водоростей, який масово вирощують для промислового виробництва нутрицевтиків у формі таблеток чи порошку. У процесі культивування нами розроблено методику збагачення альгобіомаси водорості та ії окремих складових (передусім ліпідної фракції) Селеном, Цинком i Хромом як важливими регуляторними мікроелементами. Відтак, із хлорели отримані елементвмісні ліпідні комплекси, сталість складу та структури яких підтверджено хроматографічним та мас-спектрометричним аналізом. При згодовуванні крохмальних розчинів селенцинкліпідного та селенхромліпідного комплексів здоровим щурам інтоксикації не виявлено (загальний вміст МСМ знижувався до 1,5 раза, знижувалися також вміст ТБК-АП та ДК), активізувалися антиоксидантні процеси (зростання вмісту ВГ та активності ГПО при зниженні функціональної ролі КТ) та енергетичні процеси (за рахунок підвищення активності СДГ і ЦО, ГДГ- шляху утворення глутамату), що сприяло успішному функціонуванню антиоксидантної системи та підтриманню енергетичного і метаболічного гомеостазу в організмі. Отримані результати відкривають можливість для використання біологічно активних добавок із хлорели, збагачених мікроелементами $\mathrm{Se}$ (IV), $\mathrm{Zn}$ (II) i Cr (III), що є підставою для подальших досліджень біологічної активності отриманих комплексів.

Ключові слова: Chlorella vulgaris, мікроелементи (Селен, Цинк, Хром), шурі, метаболізм, регуляція.

Сьогодні проблема хімічного забруднення довкілля та внутрішнього середовища організму залишається надзвичайно важливою та потребує нових науково обгрунтованих підходів щодо ії вирішення. Теорії, які пов'язують розвиток багатьох патологій 3 дефіцитом макро- i мікроелементів, відносяться до найсучасніших наукових розробок і напрямків, а питання подолання дефіциту мікроелементів шляхом збагачення продуктів харчування 3 принципово новими властивостями набуває все більшої популярності завдяки інтенсивному за останні роки розвитку різних біотехнологій $[23,30,36]$.

Мікроводорості - потенційне джерело широкого спектру біохімічних сполук (протеїни, поліненасичені жирні кислоти, каротиноїди, фікобіліпротеїни, полісахариди) 3 високою можливістю практичного використання і здатністю їх отримання в біотехнологічних процесах [36]. Тому в сучасній фармації та сільському господарстві активно використовують одноклітинні водорості роду Chlorella або інші види як додаткове джерело мікроелементів, протеїнів і ліпідів різної природи та в експериментах для визначення метаболічних механізмів засвоювання, надлишку чи дефіциту неорганічних та органічних нутрієнтів.

50 ISSN 2078-2357. Наук. зап. Терноп. нац. пед. ун-ту. Сер. Біол., 2020, № 3-4 (80) 
Доведено, що Цинк, Магній, Залізо, Селен, Йод та інші мікроелементи в органічній формі мають вищу, ніж мінеральні форми, біодоступність та кращу тенденцію до скорочення їх дефіциту в організмі $[9,23,24,30]$. Тому у дослідах [21] було надано перевагу у використанні як харчової добавки мікробного лізату зі збагаченої Селеном біомаси дріжджів чи лактобацил. Автори виявили, що у результаті їх засвоєння, концентрації Селену в тканинах і рідинах організму щурів були вищими, ніж за використання добавки з неорганічним Se [21]. Також кращі результати щодо зниження рівня ПОЛ та підвищення активності глутатіон-пероксидази були продемонстровані в курчат-бройлерів за введення в їх харчовий раціон органічних форм $\mathrm{Se}, \mathrm{Zn}$ i Cr, в порівнянні із введенням неорганічних солей цих мікроелементів [31].

Селен, Цинк і Хром є важливими елементами для метаболізму, бо їх роль, передусім, обумовлена безпосередньою каталітичною дією в реакціях проміжного обміну та опосередкованому інгібуванні токсичної дії важких металів [29], також ці мікроелементи беруть участь у клітинному захисті від вільнорадикальних процесів, а Хром знижує рівень глюкози в крові та покращує метаболічні процеси за цукрового діабету. Додаткове використання цих мікроелементів може слугувати профілактичним засобом для запобігання багатьох захворювань або за їх лікування $[31,39]$.

Отже, отримання та оцінка біологічної дії органічних комплексів Селену та металівмікроелементів Цинку і Хрому з водоростей, які надходять в харчові ланцюги людей і тварин через продукти харчування і виконують важливу роль в метаболізмі, що порушується за їх дефіциту, становлять значний практичний інтерес [24, 30, 39].

\section{Матеріал і методи досліджень}

Дослідження проводили на мікропопуляціях альгологічно чистої культури Chlorella vulgaris Beij. HPDP-119, яку вирощували в умовах накопичувальної культури на середовищі Фітцджеральда в модифікації Цендера і Горхема № 11 за температури $22-25^{\circ} \mathrm{C}$ та освітленні 2500 лк 16/8 год [12]. В експерименті згідно попередніх результатів [2, 28] до культури водоростей додавали водний розчин натрій селеніту в розрахунку на $\mathrm{Se}$ (IV) $-10,0$ мг/дм ${ }^{3}$ окремо та спільно $з$ водним розчином $\mathrm{ZnSO}_{4} \cdot 7 \mathrm{H}_{2} \mathrm{O}$ з кількістю $\mathrm{Zn}$ (II) - 5,0 мг/дм або з водним розчином $\mathrm{CrCl}_{3} \cdot 6 \mathrm{H}_{2} \mathrm{O}$ з кількістю $\mathrm{Cr}(\mathrm{III})-5,0$ мг/дм ${ }^{3}$. Біомасу клітин відбирали на 7-му добу культивування в присутності мікроелементів. Ліпіди 3 біомаси водоростей екстрагували хлороформ-метаноловою сумішшю у відношенні 2:1 за методом Фолча в модифікації [5]. Неліпідні домішки з екстракту видаляли відмиванням $1 \%$ розчином $\mathrm{KCl}$. Загальну кількість ліпідів визначали ваговим методом після відгонки екстрагуючої суміші [5, 11]. Кількості Селену, Цинку та Хрому в ліпідному комплексі визначали після їх озолювання нітратною кислотою $\left(\mathrm{HNO}_{3}\right)$ в герметичних бюксах при $\mathrm{t}=120^{\circ} \mathrm{C}$ протягом 2 год $[3,17,19]$.

Постановка експерименту. Наважку виділеного 3 хлорели ліофілізованих ліпідного, селенліпідного, селенцинкліпідного та селенхромліпідного комплексів розчиняли в $1 \%$ водному розчині крохмалю. Досліди проводили на білих безпородних щурах-самцях з масою тіла 160-180 г, яких утримували на стандартному раціоні віварію та розділили на відповідні групи. Перша група щурів - інтактні (контроль), отримували фізрозчин, щурам другої групи вводили ліпідну суспензію $з$ хлорели, третьої групи - селенліпідну суспензію, а тваринам четвертої і п’ятої груп - відповідно селенцинкліпідну та селенхромліпідну суспензії (табл. 1). Усі варіанти суспензій були приготовлені на основі 1 \% водного розчину крохмалю та вводилися щурам щоденно по 1 мл внутрішньошлунково упродовж 14 діб.

Запропоновані кількості мікроелементів не перевищували щоденних фізіологічних норм ïx споживання [4]. На 14-у добу від початку експерименту проводили забій тварин шляхом евтаназії під тіопенталом натрію. Кров забирали із серця тварин, яку центрифугували при 3000 об./хв протягом 30 хв. Отриману сироватку крові (надосадову рідину) використовували для проведення досліджень. Відібрану печінку (250 мг) використовували для отримання гомогенату методом диференційного гомогенізування, яке проводили після попередньої перфузії з 2,5 мл фізіологічного розчину. 
Розподіл здорових щурів та умови отримання ними елементвмісних ліпідних комплексів 3

Chlorella vulgaris

\begin{tabular}{|c|l|}
\hline Групи щурів & \multicolumn{1}{|c|}{ Умови досліду } \\
\hline I & контроль -1 мл фізіологічного розчину \\
\hline II & крохмальна суспензія, яка містила 0,5 мг ліпідів \\
\hline III & крохмальна суспензія, яка містила 0,4 мкг $\mathrm{Se}(\mathrm{IV})+0,5$ мг ліпідів \\
\hline IV & крохмальна суспензія, яка містила 0,4 мкг $\mathrm{Se}(\mathrm{IV})+2,5$ мкг $\mathrm{Zn}(\mathrm{II})+0,5$ мг ліпідів \\
\hline $\mathrm{V}$ & крохмальна суспензія, яка містила 1,85 мкг $\mathrm{Se}(\mathrm{IV})+1,1$ мкг $\mathrm{Cr}(\mathrm{III})+0,45$ мг ліпідів \\
\hline
\end{tabular}

Активність вільнорадикальних процесів в організмі щурів оцінювали за вмістом дієнових коньюгатів [6] та кислотних тіобарбітур-активних продуктів (ТБК - АП) [10] у сироватці крові та гомогенаті печінки. Ступінь ендогенної інтоксикації визначали за вмістом молекул середньої маси (МСМ) в сироватці крові [16]. Метод полягає у виділенні кислоторозчинної фракції молекул середньої маси 3 наступною детекцією десятикратно розведеної надосадової рідини при довжинах хвиль 254 та 280 нм проти дистильованої води на СФ-46.

Стан антиоксидантної системи вивчали за активністю каталази, глутатіонпероксидази, супероксиддисмутази та відновленого глутатіону. Принцип методу визначення активності каталази (КТ, КФ 1.11.1.6) грунтується на здатності пероксиду водню в присутності ензиму утворювати 3 амоній молібдатом стійкий забарвлений комплекс жовтого кольору [7]. Активність супероксиддисмутази (СОД, КФ 1.15.1.1) визначали за рівнем інгібування ензимом відновлення нітросинього тетразолію за участі НАДН і феназинметасульфату [18], а глутатіонпероксидази (ГПО, КФ 1.11.1.9) - за методом [13], в основу якого покладено кольорову реакцію при взаємодія SH-груп з реактивом Елмана (0,01 M розчин 5,5-дитіобіс-2нітробензойної кислоти на метанолі) з утворенням забарвленого продукту - тіонітрофенільного аніону. Для визначення вмісту відновленого глутатіону (ВГ) використовували метод [25], принцип якого полягає у взаємодії 5,5-дитіобіс (2-нітробензойної) кислоти (реактив Елмана) 3 вільними SН-групами відновленого глутатіону з утворенням тіонітрофенильного аніону жовтого кольору, кількість якого прямопропорційна вмісту SH-груп.

У печінці визначали активність ензимів енергетичного метаболізму: сукцинатдегідрогенази (СДГ, КФ 1.3.99.1) - за окисленням сукцинату до фумарату ферриціанідом калію, що реєстрували спектрофотометрично при довжині хвилі 420 нм [11]; цитохромоксидази (ЦО, КФ 1.9.3.1) - за конденсацією $\alpha$-нафтолу та пфенілендиамінгідрохлориду з утворенням фенолу (540 нм) [37]; глутаматдегідрогенази (ГДГ, КФ 1.4.1.2) - за швидкістю окислення НАДН або НАДФН при 340 нм [15].

Кількість білку визначали за Lowry et al. [27].

Одержані результати оброблені з використанням методів варіаційної статистики за допомогою програми Statistica 6,0.

\section{Результати досліджень та їх обговорення}

Аналіз отриманих результатів попередніх експериментів [2, 28] та літературних даних [23, 35] щодо підбору оптимальних умов вирощування Ch. vulgaris у накопичувальній культурі для отримання потенційної сировини показали, що найефективнішими умовами $є$ культивування водорості протягом 7 діб з додатковим введенням натрію селеніту в концентрації 10,0 мг $\mathrm{Se}$

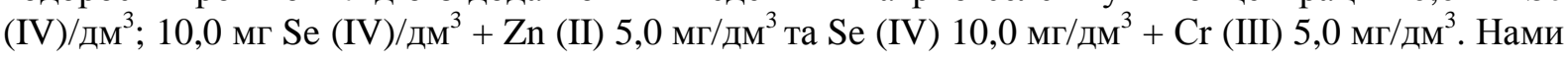
підтверджена достовірна ефективність накопичення зазначених мікроелементів біомасою хлорели і включення їх до складу ліпідів водорості, а також можливість отримання очищеного елементвмісного ліпідного комплексу $[1,8]$.

Зазначимо, що результати дослідження трансмісійної електронної мікроскопії щодо впливу металів на багату ліпідами зелену водорість Chlorella minutissima, показали, що іiі клітини за стандартних умов культивування мали круглу форму з невеликими вкрапленнями 
ліпідів без очевидної підвищеної електронної густини цих гранул. За додавання металів (Zn, $\mathrm{Mn}, \mathrm{Cd}$ та $\mathrm{Cu}$ ) у середовище вирощування, морфологія клітин змінювалася - вони стали неправильної форми, однак це не впливало на утворення ліпідних крапель, навпаки - вони ставали чіткішими і більшими та мали підвищену електронну щільність. Ліпідні гранули утворювалися не лише у цитоплазмі, а й у середині та подекуди на поверхні клітинної мембрани. Додаткові дослідження підтвердили, що до складу цих ліпідів однозначно включалися зазначені метали, проте процес залежав і від умов зростання - $\mathrm{pH}$, температури $\mathrm{i}$ часу дії [40].

Слід відзначити, що чимало наукових робіт показують ефективність відновлення мікроелементного балансу, а відтак покращання метаболічних процесів, за допомогою водоростевих добавок, що мали суттєву перевагу над неорганічними. У дослідженнях на щурах [20] порівняли біодоступність неорганічного селеніту, селенметіоніну та витяжки $3 \mathrm{Se}-$ збагаченої біомаси Spirulina, клітини якої попередньо піддавали руйнуванню та ультрацентрифугували для отримання супернатанту. 3'ясували, що Селен у складі високомолекулярних сполук з витяжки водорості мав найвищу засвоюваність, його достатні кількості знайдені в печінці та нирках, а активність глутатіонпероксидази у печінці, нирках, плазмі та еритроцитах була в межах 106-133 \% щодо контролю.

Введення в харчовий раціон курчат-бройлерів 3 мкг/кг Селену з суспенцією Se-дріжджів та $\mathrm{Se}-$ хлорели достовірно збільшувало концентрацію $\mathrm{Se}$ в м'язовій тканині та підвищило окисну стабільність курячого м'яса, порівняно з неорганічною формою цього мікроелементу [32].

Вчений Скріван М. зі співавторами [34] досліджували вплив різних форм Селену на вміст Se та вітаміну E у яєчному жовтку та курячому м'ясі. Їх результати підтвердили, що вміст Se у м'ясі грудинок і стегон та $\alpha$-токоферолу в яйцях бройлерів були значно вищими за додавання у раціон органічного Селену зі збагаченою біомасою Scenedesmus quadricauda та Chlorella vulgaris порівняно $з$ додаванням аналогічної концентрацій неорганічного натрію селеніту [34].

Окрім цього, встановлено позитивний ефект [38] селенових органічних добавок, отриманих з біомаси хлорели, на репродуктивну функцію овець. У тварин за цих умов також збільшувався вміст Se в сироватці крові і молоці та активність глутатіонпероксидази як в дорослих, так і в новонароджених ягнят, що обумовлювало загальне підвищення імунних процесів.

Отже, включення за допомогою водоростей органічних джерел Селену та інших мікроелементів у харчовий раціон сільськогосподарських та експериментальних тварин має перевагу над неорганічними формами в підвищенні метаболічного статусу організму та харчової цінності продуктів для споживання, включно людиною.

Дослідження впливу екстракту ліпідів, селенліпідного та селенцинкліпідного комплексів iз хлорели на оксидативний статус щурів показало (табл. 2), що використані нами елементвмісні ліпідні комплекси пригнічували активність окиснювальних процесів у сироватці крові та печінці дослідних тварин.

Загальновідомо, що рівень молекул середньої маси варіює залежно від метаболічного стану організму i, певною мірою, $є$ прогностичним критерієм порушення обмінних процесів. Основна частина МСМ - олігопептиди, представлена речовинами пептидної природи, які виконують різні функції, у тому числі й регуляторні $[14,16]$. Дослідження вмісту МСМ у сироватці крові здорових щурів після введення до їх організму ліпідного, селенліпідного та селенцинкліпідного комплексів із хлорели (див табл. 2) показало суттєве зниження їх вмісту. Найбільш ефективним виявився селенліпідний комплекс, який викликав зниження вмісту $\mathrm{MCM}_{1}$ у 1,4 раза, вмісту $\mathrm{MCM}_{2}$ - у 1,3 раза. Можливо, однією із причин зниження вмісту МСМ у сироватці крові здорових тварин було конкурування комплексів із глутатіоном, вміст якого активно збільшувався в дослідних щурів. 
Вплив елементвмісних ліпідних комплексів з Селеном та Цинком з Ch. vulgaris на метаболічні показники здорових щурів, $\mathrm{M} \pm \mathrm{m}, \mathrm{n}=7$

\begin{tabular}{|c|c|c|c|c|}
\hline Показники & Контроль & $\begin{array}{l}\text { Ліпідний } \\
\text { комплекс }\end{array}$ & $\begin{array}{c}\text { Se-ліпідний } \\
\text { комплекс }\end{array}$ & $\begin{array}{c}\mathrm{Se}-\mathrm{Zn} \text {-ліпідний } \\
\text { комплекс }\end{array}$ \\
\hline \multicolumn{5}{|c|}{ сироватка крові } \\
\hline ДК, ум. од/мл & $12,04 \pm 0,96$ & $11,28 \pm 0,84$ & $9,15 \pm 0,42 *$ & $8,56 \pm 0,51 *$ \\
\hline ТБК-АП, мкмоль/дм ${ }^{3}$ & $18,99 \pm 1,63$ & $19,28 \pm 1,12$ & $15,44 \pm 0,76$ & $14,57 \pm 0,32 *$ \\
\hline КТ, мкат/дм ${ }^{3}$ & $0,15 \pm 0,01$ & $0,18 \pm 0,008$ & $0,19 \pm 0,01^{*}$ & $0,22 \pm 0,01^{*}$ \\
\hline ВГ, мкмоль/мл & $0,27 \pm 0,01$ & $0,44 \pm 0,03 *$ & $0,58 \pm 0,03 *$ & $0,71 \pm 0,03 *$ \\
\hline $\mathrm{MCM}_{1,}$ од & $0,77 \pm 0,05$ & $0,54 \pm 0,04 *$ & $0,49 \pm 0,07 *$ & $0,52 \pm 0,03 *$ \\
\hline $\mathrm{MCM}_{2, \text { од }}$ & $0,59 \pm 0,05$ & $0,55 \pm 0,03$ & $0,42 \pm 0,03 *$ & $0,50 \pm 0,03$ \\
\hline \multicolumn{5}{|c|}{ печінка } \\
\hline ДК, ум. од/Г & $6,86 \pm 0,59$ & $7,74 \pm 0,62$ & $5,92 \pm 0,23 *$ & $4,35 \pm 0,21 *$ \\
\hline ТБК-АП, мкмоль/кг & $84,40 \pm 5,83$ & $92,95 \pm 5,43$ & $88,41 \pm 7,98$ & $91,88 \pm 8,22$ \\
\hline КТ, мкат/кг & $0,25 \pm 0,01$ & $0,27 \pm 0,01 *$ & $0,27 \pm 0,01 *$ & $0,28 \pm 0,01^{*}$ \\
\hline ВГ, мкмоль/г & $0,63 \pm 0,06$ & $0,92 \pm 0,02 *$ & $0,97 \pm 0,03 *$ & $1,06 \pm 0,02 *$ \\
\hline
\end{tabular}

Примітка: * - p<0,05 різниця вірогідна порівняно з контролем.

Результати досліджень щодо вмісту МСМ дозволяють припустити можливість застосування використаних нами дослідних комплексів за різних патологічних станів організму, які супроводжуються підвищенням ендогенної інтоксикації та збільшенням кількості середньомолекулярних пептидів. В умовах патології ліпідний комплекс із хлорели, збагачений мікроелементами, очевидно, зможе кон'югувати із середніми молекулами, що активізуватиме дезінтоксикаційні процеси в організмі.

Разом 3 тим, вивчення процесів ліпопероксидації дало змогу відзначити зменшення вмісту ТБК-АП та ДК у сироватці крові щурів при застосуванні селенліпідного комплексу відповідно на 18,7 \% та на 24,0 \% порівняно 3 контролем, після застосування селенцинкліпідного комплексу вміст цих продуктів знизився відповідно на 23,2 \% та 28,9 \% щодо контролю. Обидва мікроелементи, які є у складі комплексу, ймовірно, включалися в активні центри ензимів антиоксидантного захисту, що і сприяло більш вираженому пригніченню активності ПОЛ.

У печінці (див. табл. 2) спостерігали протилежні зміни активності процесів ліпопероксидації. Нами виявлено незначне зростання вмісту ТБК-АП при застосуванні усіх досліджуваних комплексів, хоча відмінності показників у групах не $\epsilon$ вірогідними, однак вміст дієнових кон'югатів був нижчим від значень у контролі на 13,7 \% за введення селенліпідного та на 36,5 \% за введення селенцинкліпідного комплексу.

У зв'язку $з$ цим, доцільним було також дослідити активності ензимних компонентів антиоксидантного захисту організму. Встановлено, що після застосування усіх досліджуваних комплексів у сироватці крові вірогідно збільшувалися активність каталази та кількість відновленого глутатіону (див. табл. 2). За дії ліпідного комплексу активність КТ і кількість ВГ збільшилися порівняно з контролем відповідно на 20,0 \% і 63,0 \%, за дії селенліпідного комплексу - на 26,7 \% і 114,8 \% відповідно, а за дії селенцинкліпідного комплексу - на 46,0 \% і $163,0 \%$. Також відзначимо, що ці показники певною мірою підвищилися і в печінці: активність КТ - на 8,0 \% за дії ліпідного та селенліпідного комплексів і на 12,0 \% - за дії селенцинкліпідного комплексу; тоді як кількість ВГ збільшилася на 46,0 \% за дії ліпідного комплексу, на 54,0 \% - за дії селенліпідного комплексу і на 68,3 \% - за дії селенцинкліпідного комплексу щодо контролю.

Можливо, що мікроелементи в складі ліпідів легко проникають через плазматичні мембрани в клітини, тому отримані результати 3 вивчення показників антиоксидантного статусу підтверджують наше припущення про активне включення $\mathrm{Se}$ i $\mathrm{Zn}$ у метаболічні 54 ISSN 2078-2357. Наук. зап. Терноп. нац. пед. ун-ту. Сер. Біол., 2020, № 3-4 (80) 
процеси, що обумовлюють загалом зниження інтенсивності окиснювальних процесів в організмі $[28,30]$.

Зазначимо, що останнім часом велике значення у метаболізмі тварин і людини надається різним пептидам, які відіграють ключову роль у процесах взаємодії зі сполуками ендогенного та екзогенного характеру. Так, для інактивації ряду ліків необхідна кон'югація з трипептидом глутатіоном. Відповідно, потенціювання ефектів ліків може спостерігатися при конкуруванні за одні й ті ж ендогенні субстрати - пептиди, знижуючи їх рівень [22], тому збільшення ВГ як важливого компонента антиоксидантного захисту може виявитися позитивним аспектом у терапевтичних заходах.

Відомо, що ефективне функціонування енергетичних систем в організмі $є$ важливим критерієм успішного формування адаптаційних стратегій. Для підтвердження ефективності та надійності елементвмісних комплексів вивчили активність сукцинатдегідрогенази (СДГ), цитохромоксидази (ЦО), а також глутаматдегідрогенази (ГДГ-НАД(Ф)) за їх впливу в печінці здорових щурів (табл. 3).

Таблиия 3

Вплив елементвмісних ліпідних комплексів з Селеном та Цинком з Ch. vulgaris на енергетичні процеси в печінці здорових щурів, $\mathrm{M} \pm \mathrm{m}, \mathrm{n}=7$

\begin{tabular}{|c|c|c|c|c|}
\hline Показники & Контроль & $\begin{array}{c}\text { Ліпідний } \\
\text { комплекс }\end{array}$ & $\begin{array}{c}\text { Sе-ліпідний } \\
\text { комплекс }\end{array}$ & $\begin{array}{c}\text { Se-Zn-ліпідний } \\
\text { комплекс }\end{array}$ \\
\hline $\begin{array}{c}\text { СДГ, нмоль сукцинату/ мГ } \\
\text { протеїну*хв }\end{array}$ & $45,61 \pm 4,32$ & $48,54 \pm 5,56$ & $43,87 \pm 3,57$ & $60,28 \pm 5,77 *$ \\
\hline $\begin{array}{c}\text { ЦО, мкг індофенолу синього/мг } \\
\text { протеїну 20 хв }\end{array}$ & $61,36 \pm 3,67$ & $75,65 \pm 4,22 *$ & $61,17 \pm 2,37$ & $76,82 \pm 3,30^{*}$ \\
\hline $\begin{array}{c}\text { НАД-ГДГ, } \\
\text { нмоль НАДН/мг протеїну *хв }\end{array}$ & $1,79 \pm 0,09$ & $1,66 \pm 0,06$ & $1,07 \pm 0,04 *$ & $1,21 \pm 0,08 *$ \\
\hline $\begin{array}{c}\text { НАДФ-ГДГ, } \\
\text { нмоль НАДФН/мг протеїну *хв }\end{array}$ & $2,08 \pm 0,12$ & $2,41 \pm 0,14 *$ & $2,56 \pm 0,18^{*}$ & $2,85 \pm 0,11$ \\
\hline НАД-ГДГ/ НАДФ-ГДГ & 0,86 & 0,69 & 0,42 & 0,42 \\
\hline
\end{tabular}

Примітка: * - p<0,05 різниця вірогідна порівняно з контролем.

Отримані результати показали, що ліпідний екстракт та його селеновий комплекс практично не впливали на активність СДГ, а активність ЦО збільшилася лише за дії ліпідів окремо (на 23,3\%). При цьому, селенцинкліпідний комплекс збільшував активність СДГ та ЦО відповідно на $32,2 \%$ та 25,2 \% порівняно зі значеннями у контрольній групі щурів.

Відомо, що спрямованість глутаматдегідрогеназної реакції, яка $\epsilon$ оборотною, визначається наявністю коензиму: НАД - пряма, НАДФ - зворотна, що обумовлює особливості метаболізму [29]. Визначено, що НАДН-глутаматдегідрогеназна активність в усіх варіантах експерименту знижувалася, особливо за дії селенліпідного та селенцинкліпідного комплексів 3 хлорели, на 40,2 \% і 32,4 \% порівняно 3 контролем (див. табл. 3). Натомість активність НАДФН-ГДГ за введення щурам ліпідного, селенліпідного і селенцинкліпідного комплексів збільшувалася відповідно на $16,1 \%, 23,6$ \% та $37,5 \%$ щодо показника у тварин контрольної групи.

Співвідношення НАДН-ГДГ/НАДФН-ГДГ за дії ліпідного, селен-ліпідного і селенцинкліпідного комплексів зменшувалося відповідно на 20,9 \%, 51,2 \% та 24,4 \% порівняно 3 контролем, що свідчить про часткову активізацію синтазної ланки азотного метаболізму. Переважання амінування кетокислот та утворення глутамату, а з нього - інших амінокислот, може відбуватися у зв'язку з посиленим утворенням протеїнових сполук компонентів антиоксидантної системи - каталази і відновленого глутатіону, що виявлено в експериментальних тварин як в печінці, так і в сироватці крові.

Щодо впливу ліпідного комплексу із Селеном і Хромом 3 Ch.vulgaris на організм здорових щурів, то отримані результати засвідчили, як і у випадку з селенцинкліпідним 
комплексом, що введення щурам цих комплексів із водорості не викликало ендогенної інтоксикації в організмі останніх, оскільки відбулося зниження вмісту молекул середньої маси у крові тварин (табл. 4). Кількість $\mathrm{MCM}_{1}$ за введення обох досліджуваних комплексів зменшилася на $6 \%$, а $\mathrm{MCM}_{2}$ - за умов введення ліпідного комплексу - на $60 \%$, а селенхромліпідного - на 53,9\%. Дослідження передусім рівня МСМ було важливим з огляду на відносну токсичність Хрому, оскільки цей елемент може спричинити більші потенційні негативні наслідки для організму, ніж Селен чи Цинк.

Таблиия 4

Вплив елементвмісних ліпідних комплексів з Селеном та Хромом з Ch. vulgaris на метаболічні показники здорових щурів, $\mathrm{M} \pm \mathrm{m}, \mathrm{n}=7$

\begin{tabular}{|c|c|c|c|}
\hline Показники & Контроль & Ліпідний комплекс & $\begin{array}{c}\text { Se-Сr-ліпідний } \\
\text { комплекс }\end{array}$ \\
\hline \multicolumn{4}{|c|}{ сироватка крові } \\
\hline ДК, ум. од/мл & $8,68 \pm 0,64$ & $5,27 \pm 0,39^{*}$ & $3,96 \pm 0,33^{*}$ \\
\hline ТБК-АП, мкмоль/дм ${ }^{3}$ & $56,42 \pm 4,6$ & $43,19 \pm 3,93^{*}$ & $30,07 \pm 2,24^{*}$ \\
\hline Каталаза, мкат/дм ${ }^{3}$ & $2,23 \pm 0,19$ & $3,41 \pm 0,32^{*}$ & $5,79 \pm 0,23^{*}$ \\
\hline СОД, ум. од/мл & $0,65 \pm 0,05$ & $0,35 \pm 0,03$ & $0,16 \pm 0,01^{*}$ \\
\hline ГПО, ммоль/хвхдм ${ }^{3}$ & $0,09 \pm 0,01$ & $0,13 \pm 0,01$ & $0,56 \pm 0,05$ \\
\hline ВГ, мкмоль/мл & $6,63 \pm 0,56$ & $9,18 \pm 0,87$ & $16,86 \pm 1,37$ \\
\hline МСМ, од & $0,16 \pm 0,01$ & $0,15 \pm 0,01^{*}$ & $0,15 \pm 0,01^{*}$ \\
\hline МСМ 2, од & $0,24 \pm 0,02$ & $0,15 \pm 0,01$ & $0,16 \pm 0,01^{*}$ \\
\hline \multicolumn{4}{|c|}{ печінка } \\
\hline ДК, ум. од/г & $1,57 \pm 0,15$ & $1,26 \pm 0,13$ & $1,2 \pm 0,09 *$ \\
\hline ТБК-АП, мкмоль/кг & $59,85 \pm 5,83$ & $52,99 \pm 3,13^{*}$ & $50,21 \pm 4,98^{*}$ \\
\hline Каталаза, мкат/кг & $1,37 \pm 0,06$ & $0,99 \pm 0,07$ & $0,85 \pm 0,03^{*}$ \\
\hline СОД, ум. од/мг & $8,09 \pm 0,65$ & $2,61 \pm 0,02^{*}$ & $4,13 \pm 0,33^{*}$ \\
\hline ГПО, ммоль/хвхкг & $0,03 \pm 0,002$ & $0,09 \pm 0,01^{*}$ & $1,05 \pm 0,09^{*}$ \\
\hline ВГ, мкмоль/Г & $162,31 \pm 14,54$ & $180,32 \pm 10,87$ & $333,15 \pm 11,52^{*}$ \\
\hline
\end{tabular}

Примітка: * - p<0,05 різниця вірогідна порівняно з контролем.

Зазначимо, що за дії Хрому можуть активізуватися процеси ліпопероксидації, тому їх вивчення дозволило засвідчити про достовірне зниження вмісту ДК у сироватці крові на 39,3\% за застосування ліпідної суспензії та на 54,4 \% за дії селенхромліпідного комплексу порівняно 3 контролем, у печінці - відповідно на 19,8 \% та 23,6 \% (див. табл. 4).

Введення щурам ліпідного та селенхромліпідного комплексів показало, що вміст ТБКАП у крові знизився на 23,5 \% і 46,7 \% щодо контролю, у печінці - на 11,5 \% за дії ліпідного комплексу і на $16,0 \%$ за дії селенхромліпідного комплексу. Варто зауважити, що включені в складі ліпідів Селен та Хром загалом зменшують процеси ліпопероксидації в 1,2-1,4 раза інтенсивніше порівняно з лише ліпідним комплексом з хлорели. Ймовірно, мікроелементи, $\mathrm{Cr}$ i $\mathrm{Zn}$ у комплексі з ліпідами, активують компоненти антиоксидантного захисту, що сприяє більш вираженому пригніченню активності процесів ПОЛ в організмі здорових тварин.

Водночас визначено, що після застосування комплексів у сироватці крові зростала активність КТ: за дії ліпідного - на 55,2 \%, а селенхромліпідного комплексу - на 260,1 \% щодо показника у тварин контрольної групи. Проте у печінці активність цього ензиму знижувалася на $25,3 \%$ та $38,0 \%$ відповідно до контролю. Зниження активності СОД порівняно 3 контрольними значеннями відмічено як за дії ліпідного екстракту, так і селенхромліпідного комплексу в сироватці крові (у 2-4 рази), і в печінці щурів (у 2-3 рази).

Разом $з$ тим, активність ГПО, яка каталізує відновлення пероксидів ліпідів у відповідні спирти і відновлення гідроген пероксиду до води, суттєво підвищувалася в крові, а особливо в печінці дослідних тварин. За введення щурами ліпідного комплексу ГПО активувалася 
меншою мірою, тоді як за введення селенхромліпідного комплексу - у крові у 6,2 раза, а у печінці - аж у 32,5 раза. Ензими сімейства глутатіонпероксидаз $є$ селенвмісними тетрамерними глікопротеїнами, чим можна пояснити значну активацію ГПО в щурів за дії досліджуваного селенхромліпідного комплексу [29]. Окрім цього, підвищення активності ГПО в печінці відбувалося на тлі зниження активності КТ та СОД, як, очевидно, один з компенсаторних механізмів для забезпечення належного функціонування антиоксидантної системи. Водночас, можливо, має місце певна модифікація їх активних центрів ліпідами 3 хлорели за рахунок включення у них атомів Селену та Хрому.

Зазначимо, що вміст відновленого глутатіону узгоджувався із зростанням активності ГПО (табл. 4). Так, вміст ВГ у сироватці крові тварин за введення ліпідного комплексу збільшувався на 38,4\%, а селенхромліпідного - на $154,3 \%$, у печінці - відповідно на $11,1 \%$ та 20,3\% порівняно 3 контрольними показниками.

Отже, за зниження ролі КТ та СОД у знешкодженні пероксидних сполук, насамперед у сироватці крові, головним компонентом антиоксидантного захисту за дії ліпідного та селенхромліпідного комплексу в організмі здорових щурів виступає глутатіонова система.

Важливим етапом нашого дослідження було порівняння активності ензимів, які контролюють енергетичний метаболізм - СДГ, ЦО та ГДГ (табл. 5). Виявлено, що введення як ліпідного, так і селенхромліпідного комплексу зумовлювали підвищення активності СДГ та ЦО в печінці піддослідних тварин.

Таблиия 5

Вплив елементвмісних ліпідних комплексів з Селеном та Хромом з Ch. Vulgaris на енергетичні процеси в печінці здорових щурів, $\mathrm{M} \pm \mathrm{m}, \mathrm{n}=7$

\begin{tabular}{|c|c|c|c|}
\hline Показники & Контроль & Ліпідний комплекс & $\begin{array}{c}\text { Se-Сr-ліпідний } \\
\text { комплекс }\end{array}$ \\
\hline СДГ, нмоль сукцинату/ мг протеїну*хв & $38,72 \pm 1,62$ & $40,73 \pm 2,55$ & $61,85 \pm 3,62^{*}$ \\
\hline $\begin{array}{c}\text { ЦО, мкг індофенолу синього/мг протеїну } \\
\text { за 20 хв }\end{array}$ & $74,33 \pm 2,67$ & $89,12 \pm 4,52^{*}$ & $85,76 \pm 5,30^{*}$ \\
\hline НАД-ГДГ, нмоль НАДН/мг протеїну*хв & $3,36 \pm 0,31$ & $2,27 \pm 0,12$ & $13,79 \pm 0,55^{*}$ \\
\hline $\begin{array}{c}\text { НАДФ-ГДГ, нмоль НАДФН/мг } \\
\text { протеїну*хв }\end{array}$ & $8,16 \pm 0,69$ & $1,27 \pm 0,10^{*}$ & $12,07 \pm 0,96^{*}$ \\
\hline НАД-ГДГ/НАДФ-ГДГ & 0,41 & 1,79 & 1,14 \\
\hline
\end{tabular}

Примітка: * - $<0,05$ різниця вірогідна порівняно з контролем.

3'ясовано, що за введення щурам ліпідного екстракту активність сукцинатдегідрогенази практично не змінювалася, тоді як за споживання селенхромліпідного комплексу вона збільшилася майже на $60 \%$, а цитохромоксидаза збільшилася в обох випадках відповідно на $20 \%$ та $15 \%$ щодо їх значень у щурів контрольної групи.

Разом 3 тим, НАДН-глутаматдегідрогеназна активність за дії ліпідного екстракту 3 хлорели достовірно знижувалася (на $32 \%$ ), а за дії селенхромліпідного комплексу - достовірно зростала (на $410 \%$ ) (див. табл. 5). Активність НАДФН -ГДГ за введення щурам ліпідного екстракту 3 хлорели також суттєво зменшувалася - на $85 \%$, а за введення щурам селенхромліпідного комплексу достовірно зростала на 48 \% щодо показників у тварин контрольної групи.

Визначення показника співвідношення НАДН-ГДГ/НАДФН-ГДГ показало його зростання - в 4,35 раза за дії ліпідного екстракту та в 2,78 раза за споживання селенхромліпідного комплексу проти значення у тварин контрольної групи. Результати вказують про активізацію каталітичної ланки протеїнового метаболізму. Переважання утворення кетокислот у реакціях дезамінування амінокислот через глутамат, свідчить про їхнє використання в енергетичному обміні, передусім в циклі Кребса, що узгоджується зі зростанням активності СДГ, особливо за впливу селенхромліпідного комплексу з хлорели. Зниження абсолютних показників активності глутаматдегідрогеназ за дії ліпідного екстракту може бути пов'язане із використанням самих ліпідів як енергетичного субстрату, а відтак 
зменшується потреба в амінокислотах як джерелі енергії.

Щодо сукцинатдегідрогеназної активності, то вона володіє високим каталітичним потенціалом, який може бути реалізований за різних фізіологічних станів організму [11]. Ензим бере участь у здійсненні регуляції і взаємозв'язку окремих шляхів не тільки окиснювального, але й пластичного обмінів [29]. Проведені дослідження дозволили відзначити активацію ліпідним, селенліпідним, селенцинкліпідним та селенхромліпідним комплексами з хлорели окремих ланок енергетичного метаболізму в щурів. Водночас, підвищення СДГ активності узгоджувалося 3 підвищенням активності ЦО ланки електроно-транспортного ланцюга, що свідчить про перспективу регуляції метаболічних процесів за допомогою досліджуваних комплексів.

Збільшення цитохромоксидазної активності в печінці здорових тварин за дії як ліпідів окремо, так і їх комплексу з Селеном, Цинком та Хромом, може бути пов'язане зі збільшенням енерговитрат на адаптаційні процеси, насамперед біосинтез компонентів антиоксидантної системи, що за дії селенцинк- та селенхромліпідного комплексів активуються. Окрім того, жирні кислоти [33] та іони металів, включно $\mathrm{Zn}$ та $\mathrm{Cr}$, здатні активізувати каталітичні властивості ЦО на молекулярному рівні [26]. Зазначимо, що незначна модифікація енергетичного метаболізму має місце як на рівні циклу Кребса при виробництві макроергів, так і на рівні використання амінокислот як енергетичного субстрату.

\section{Висновки}

Проведені дослідження продемонстрували позитивний вплив ліпідного, селенліпідного, селенцинк- та селенхромліпідного комплексів із хлорели на метаболічні процеси в здорових щурів та розкрили перспективу їх використання як антиоксидантів та антигіпоксантів в умовах патології.

1. Боднар О. І., Вінярська Г. Б., Грубінко В. В., Лихацький П. Г., Фіра Л. С. Спосіб отримання біологічно активного селен-цинк-ліпідного комплексу 3 хлорели: пат. Україна: А61К $36 / 05$, А61К33/04, А61К33/30. № 114650; заявл. 12.10.16; опубл. 10.03.17, Бюл. № 5.4 с.

2. Вінярська Г. Б., Боднар О. І., Станіславчук А. В., Грубінко В. В. Накопичення есенціальних металів макромолекулами Chlorella vulgaris Beij. (Chlorophyta) у присутності селеніту натрію. Наук. заn. Терноп. нач. пед. ун-ту. Сер. Біол. 2015. Т. 64, № 3-4. С. 103-108.

3. Дедков Ю. М., Мусатов А.В. Селен: биологическая роль, химические свойства и методы определения. ВИНИТИ. 2001, Вып. 168. С. 19-23.

4. Доклінічні дослідження лікарських засобів. Методичні рекомендації / за заг. ред. О. В. Стефанова. Київ : Авіцена, 2001. 456 с.

5. Кейтс М. Техника липидологии. Выделение, анализ и идентификация липидов. Мир : Москва, 1975. $322 \mathrm{c}$.

6. Колесова О. Е., Маркин А. А., Федорова Т. Н. Перекисное окисление липидов и методы определения продуктов липопероксидации в биологических середах. Лабораторное дело. 1984. № 9. С. 540-546.

7. Королюк М. А., Иванова Л. И., Майорова И. Г., Токарев В. Е. Метод определения активности каталазы. Лабораторное дело. 1988. № 1. С. 6-18.

8. Лукашів О. Я., Боднар О. І., Вінярська Г. Я., Грубінко В. В. Спосіб отримання біологічно активного селенхромліпідного комплексу з хлорели: пат. Україна: А61К33/04, А61К33/30, А61К36/05. № 122227; заявл. 17.07.17; опубл. 26.12.17, Бюл. № 24. 5 c.

9. Лукашів О.Я., Вінярська Г.Б., Боднар О. І., Грубінко В. В. Вплив на метаболічні процеси в організмі селеновмісних біодобавок та перспективи їх використання. Вісник проблем біології та медииини. 2016. Т. 3 (вип. 2, № 130). С. 30-35.

10. Лущак В. І., Багнюкова Т. В., Лущак О. В. Показники оксидативного стресу. Тіобарбітурактивні продукти і карбонільні групи білків. Укр. біохім. журн. 2004. Т. 76, № 3. С. 136-141.

11. Методы биохимических исследований (липидный и энергетический обмен) : учебное пособ. / под ред. М. И. Прохоровой. Ленинград : ЛГУ, 1982. 273 с.

12. Методы физиолого-биохимического исследования водорослей в гидробиологической практике / под ред. А. В. Топачевского. Киев : Наукова думка, 1975. 248 с.

13. Моин В.М. Простой и специфический метод определения активности глутатионпероксидазы в еритроцитах. Лабораторное дело. 1986. № 12. С. 724-727. 
14. Никольская В. А., Данильченко Ю. Д., Меметова З. Н. Биохимический аспект рассмотрения роли молекул средней массы в организме. Учен. зап. Тавр. нач. унив. им. В. И. Вернадского. Сер. Биол., хим. 2013. Т. 6, № 65. С. 139-145.

15. Софьин А. В., Шатилов В. Р., Кретович В. Л. Глутаматдегидрогеназы одноклеточной зеленой водоросли Ankistrodesmus braunii. Кинетические свойства. Биохимия. 1984. Т. 49, № 2. С. 334-343.

16. Туряница И. М., Ростока Л. М., Федорович Т. М., Туряница С. М. Среднемолекулярные пептиды сыворотки крови крыс при остром повреждении печени и введении йодированного масла. Укр. биохим. журн. 1991. Т. 63, № 2. С. 102-105.

17. Хавезов И., Цалев Д. Атомно-абсорбционный анализ. Ленинград : Химия, 1983. 144 с.

18. Чевари С., Чаба И., Секей Й. Роль супероксидредуктазы в окислительных процессах клетки и метод определения ее в биологическом материале. Лабораторное дело. 1985. № 11. С. 678-681.

19. Яцків О. С., Пацай И. О. Спектрофотометричне визначення Cr (III) 3 допомогою хромазуролу S в присутності Cr (VI). Методи і об’єкти хімічного аналізу. 2009. Т. 4, № 1. C. 43-47.

20. Cases J., Wysocka I. A., Caporiccio B., Jouy N., Besançon P., Szpunar J., Rouanet J.-M. Assessment of selenium bioavailability from high-selenium Spirulina subfractions in selenium-deficient rats. J. Agric. Food Chem. 2002. Vol. 50, No 13. P. 3867-3873.

21. Chen L., Pan D.-D., Zhou J., Jiang Y.-Z. Protective effect of selenium-enriched Lactobacillus on CCl4induced liver injury in mice and its possible mechanisms. World J. Gastroenterol. 2005. Vol. 11, No 37. P. 5795-5800.

22. Clark W. R., Winchester J. F. Middle molecules and small-molecular-weight proteins in ESRD: properties and strategies for their removal. Adv. Ren. Replace Ther. 2003. Vol. 10, No 4. P. 270-278.

23. Doucha J., Livansky K., Kotrbacek V., Zachleder V. Production of Chlorella biomass enriched by selenium and its use in animal nutrition: A review. Appl. Microbiol. Biotechnol. 2009. 83. P. 1001-1008.

24. Dumont E., Vanhaecke F., Cornelis R. Selenium speciation from food source to metabolites: A critical review. Anal. Bioanal. Chem. 2006. 385. P. 1304-1323.

25. Ellman G. L. Tissne sulfhydryl groups. Arch. Bioch. Biophys. 1959. 82. P. 70-77.

26. Horveth I., Ittel N., van Leeuwen D. Catalysis by metal complexes. Activation and catalytic reactions of saturated hydrocarbons in the presence of metal complexes. New York- London : Kluwer Academic Publishers, 2000. Vol. 21. 550 p.

27. Lowry O. H., Rosenbroug N. I., Farr A. L., Randall R. I. Protein measurement with the Folin phenol reagent. J. Biol. Chem. 1951. Vol. 193, No 1. P. 265-275.

28. Lukashiv O. Ya., Bodnar O. I., Grubinko V. V. Accumulation of Chromium and Selenium inside cells and in lipids of Chlorella vulgaris Beij. during the incubation from chromium by sodium chloride and selenium. Int. J. Algae. 2017. Vol. 19, No 4. P. 357-366.

29. Metzler D. E. Biochemistry: The Chemical Reactions of Living Cells. $2^{\text {nd }}$ ed. New York-London : Academic Press, 2003. 1972 p.

30. Mosulishvili L. M., Kirkesali E. I., Belokobylsky A. I, Khizanishvili A. I., Frontasyeva M. V. Experimental substantiation of the possibility of developing selenium- and iodine-containing pharmaceuticals based on blue-green algae Spirulina platensis. J. Pharm. Biomed. Anal. 2002. Vol. 30, No 1. P. 87-97.

31. Rao S. V., Prakash B., Raju M. V., Panda A. K., Kumari R. K., Reddy E. P. Effect of supplementing organic forms of Zinc, Selenium and Chromium on performance, anti-oxidant and immune responses in broiler chicken reared in tropical summer. Biol. Trace Elem. Res. 2016. Vol. 172, No 1. P. 511-520.

32. Sevcikova S., Skrivan M., Dlouha G., Koucky M. The effect of selenium source on the performance and meat quality of broiler chickens. Czech. J. Anim. Sci. 2006. 51. P. 449-457.

33. Sharpe M., Perin I., Wrigglesworth J. Fatty acids as modulators of cytochrome $c$ oxidase in proteoliposomes. Biochem. J. 1996. Vol. 320, No 2. P. 557-561.

34. Skrivan M., Marounek M., Dlouha G., Sevcikova S. Dietary selenium increases vitamin E contents of egg yolk and chicken meat. Brit. Poultry Sci. 2008. 49. P. 482-486.

35. Skrivan M., Skrivanova V., Dlouha G., Branyikova I., Zachleder V., Vitova M. The use of selenium-enriched alga Scenedesmus quadricauda in chicken diet. Czech J. Anim. Sci. 2010. Vol. 55, No 12. P. 565-571.

36. Skulberg O. M. Bioactive chemicals in microalgae. In Handbook of Microalgal Culture: Biotechnology and Applied Phycology / ed. A. Richmond. Oxford : Blackwell Science, 2004. P. 485-512.

37. Straus W. Colometric microdetermination of cytochrome c oxidase. J. Biol. Chem. 1954. Vol. 207, No 2. P. 733-743.

38. Travnicek J., Racek J., Trefil L., Rodinova H., Kroupova V., Illek J., Doucha J., Pisek L. Activity of glutathione peroxidase (GSH-Px) in the blood of ewes and their lambs receiving the selenium-enriched unicellular alga Chlorella. Czech. J. Anim. Sci. 2008. 53. P. 292-298.

39. Vincent J. B. The Nutritional Biochemistry of Chromium (III). Tuscaloosa : Department of Chemistry the University of Alabama, USA, 2007. 277 p.

ISSN 2078-2357. Наук. зап. Терноп. нац. пед. ун-ту. Сер. Біол., 2020, № 3-4 (80) 
40. Yang J. S., Cao J., Xing L. G., Yuan H. Lipid production combined with biosorption and bioaccumulation of cadmium, copper, manganese and zinc by oleaginous microalgae Chlorella minutissima UTEX2341. Bioresour. Technol. 2015. 175. P. 537-544.

\section{References}

1. Bodnar O. I., Viniarska H. B., Grubinko V. V., Lykhatskyi P. H., Fira L. S. Sposib otrymannia biolohichno aktyvnoho selen-tsynk-lipidnoho kompleksu z khlorely: pat. Ukraina: A61K36/05, A61K33/04, A61K33/30. № 114650; zaiavl. 12.10.16; opubl. 10.03.17, Biul. № 5. 4 s. [in Ukrainian]

2. Viniarska H. B., Bodnar O. I., Stanislavchuk A. V., Grubinko V. V. Nakopychennia esentsialnykh metaliv makromolekulamy Chlorella vulgaris Beij. (Chlorophyta) u prysutnosti selenitu natriiu. Nauk. zap. Ternop. nats. ped. un-tu. Ser. Biol. 2015. T. 64, № 3-4. S. 103-108. [in Ukrainian]

3. Dedkov Yu. M., Musatov A. V. Selen: biologicheskaia rol, khimicheskie svoistva i metodu opredelenyia. VYNYTY. 2001, Vup. 168. S. 19-23. [in Russian]

4. Doklinichni doslidzhennia likarskykh zasobiv. Metodychni rekomendatsii / za zah. red. O. V. Stefanova. Kyiv : Avitsena, 2001. 456 s. [in Ukrainian]

5. Keits M. Tekhnika lipidolohii. Vudelenie, analiz i identyfykatsyia lipidov. Mir : Moskva, 1975. 322 s. [in Russian]

6. Kolesova O. E., Markin A. A., Fedorova T. N. Perekisnoe okislenie lipidov i metodu opredeleniia produktov lipoperoksidatsii v biologicheskikh seredakh. Laboratornoe delo. 1984. № 9. S. 540-546. [in Russian]

7. Koroliuk M. A., Ivanova L. I., Maiorova I. H., Tokarev V. E. Metod opredeleniia aktivnosti katalazu. Laboratornoe delo. 1988. № 1. S. 6-18. [in Russian]

8. Lukashiv O. Ya., Bodnar O. I., Viniarska H. B., Grubinko V. V. Sposib otrymannia biolohichno aktyvnoho selenkhromlipidnoho kompleksu z khlorely: pat. Ukraina: A61K33/04, A61K33/30, A61K36/05. № 122227; zaiavl. 17.07.17; opubl. 26.12.17, Biul. № 24. 5 s. [in Ukrainian]

9. Lukashiv O. Ya., Viniarska H. B., Bodnar O. I., Grubinko V. V. Vplyv na metabolichni protsesy v orhanizmi selenovmisnykh biodobavok ta perspektyvy yikh vykorystannia. Visnyk problem biolohii ta medytsyny. 2016. T. 3 (vyp. 2, № 130). S. 30-35. [in Ukrainian]

10. Lushchak V. I., Bahniukova T. V., Lushchak O. V. Pokaznyky oksydatyvnoho stresu. Tiobarbituraktyvni produkty i karbonilni hrupy bilkiv. Ukr. biokhim. zhurn. 2004. T. 76, № 3. S. 136-141. [in Ukrainian]

11. Metodu biokhimicheskikh issledovaniui (lipidnui i energeticheskii obmen) : ychebnoe posob. / pod red. M. I. Prokhorovoi. Lenyngrad : LGU, 1982. 273 s. [in Russian]

12. Metodu fiziologo-biokhimicheskogo issledovanyia vodoroslei $\mathrm{v}$ gidrobiologicheskoi praktike / pod red. A. V. Topachevskogo. Kiev : Naukova dumka, 1975. 248 s. [in Russian]

13. Moin V. M. Prostoi i spetsuficheskyi metod opredeleniia aktivnosti glutationperoksydazu v eritrotsutakh. Laboratornoe delo. 1986. № 12. S. 724-727. [in Russian]

14. Nikolskaia V. A., Danilchenko Yu. D., Memetova Z. N. Biokhimicheskiui aspekt rassmotreniia roli molekul srednei massu v orhanizme. Uchen. Zap. Tavr. nats. unyv. ym. V. Y. Vernadskogo. Ser. Biol., khim. 2013. T. 6, № 65. S. 139-145. [in Russian]

15. Sofin A. V., Shatilov V. R., Kretovich V. L. Glutamatdegydrohenazu odnokletochnoi zelenoi vodorosli Ankistrodesmus braunii. Kineticheskie svoistva. Biokhimiia. 1984. T. 49, № 2. S. 334-343. [in Russian]

16. Tyrianitsa Y. M., Rostoka L. M., Fedorovich T. M., Tyrianytsa S. M. Srednemolekuliarnue peptidu suvorotki krovi krus pri ostrom povrezhdenii pecheni i vvedenii iodirovannogo masla. Ukr. byokhym. zhurn. 1991. T. 63, № 2. S. 102-105. [in Russian]

17. Khavezov I., Tsalev D. Atomno-absorbtsionnui analiz. Leningrad : Khimiia, 1983. 144 s. [in Russian]

18. Chevari S., Chaba I., Sekei I. Rol superoksidreduktazu v okislitelnukh protsessakh kletki i metod opredeleniia ee v biologicheskom materiale. Laboratornoe delo. 1985. № 11. S. 678-681. [in Russian]

19. Iatskiv O. S., Patsai Y. O. Spektrofotometrychne vyznachennia Cr (III) z dopomohoiu khromazurolu S v prysutnosti Cr (VI). Metody i obiekty khimichnoho analizu. 2009. T. 4, № 1. S. 43-47. [in Ukrainian]

20. Cases J., Wysocka I. A., Caporiccio B., Jouy N., Besançon P., Szpunar J., Rouanet J.-M. Assessment of selenium bioavailability from high-selenium Spirulina subfractions in selenium-deficient rats. J. Agric. Food Chem. 2002. Vol. 50, No 13. P. 3867-3873.

21. Chen L., Pan D.-D., Zhou J., Jiang Y.-Z. Protective effect of selenium-enriched Lactobacillus on CCl4induced liver injury in mice and its possible mechanisms. World J. Gastroenterol. 2005. Vol. 11, No 37. P. 5795-5800.

22. Clark W. R., Winchester J. F. Middle molecules and small-molecular-weight proteins in ESRD: properties and strategies for their removal. Adv. Ren. Replace Ther. 2003. Vol. 10, No 4. P. 270-278. 
23. Doucha J., Livansky K., Kotrbacek V., Zachleder V. Production of Chlorella biomass enriched by selenium and its use in animal nutrition: A review. Appl. Microbiol. Biotechnol. 2009. 83. P. 1001-1008.

24. Dumont E., Vanhaecke F., Cornelis R. Selenium speciation from food source to metabolites: A critical review. Anal. Bioanal. Chem. 2006. 385. P. 1304-1323.

25. Ellman G. L. Tissne sulfhydryl groups. Arch. Bioch. Biophys. 1959. 82/ P. 70-77.

26. Horveth I., Ittel N., van Leeuwen D. Catalysis by metal complexes. Activation and catalytic reactions of saturated hydrocarbons in the presence of metal complexes. New York- London : Kluwer Academic Publishers, 2000. Vol. 21. 550 p.

27. Lowry O. H., Rosenbroug N. I., Farr A. L., Randall R. I. Protein measurement with the Folin phenol reagent. J. Biol. Chem. 1951. Vol. 193, No 1. P. 265-275.

28. Lukashiv O. Ya., Bodnar O. I., Grubinko V. V. Accumulation of Chromium and Selenium inside cells and in lipids of Chlorella vulgaris Beij. during the incubation from chromium by sodium chloride and selenium. Int. J. Algae. 2017. Vol. 19, No 4. P. 357-366.

29. Metzler D. E. Biochemistry: The Chemical Reactions of Living Cells. $2^{\text {nd }}$ ed. New York-London : Academic Press, 2003. 1972 p.

30. Mosulishvili L. M., Kirkesali E. I., Belokobylsky A. I, Khizanishvili A. I., Frontasyeva M. V. Experimental substantiation of the possibility of developing selenium- and iodine-containing pharmaceuticals based on blue-green algae Spirulina platensis. J. Pharm. Biomed. Anal. 2002. Vol. 30, No 1. P. 87-97.

31. Rao S. V., Prakash B., Raju M. V., Panda A. K., Kumari R. K., Reddy E. P. Effect of supplementing organic forms of Zinc, Selenium and Chromium on performance, anti-oxidant and immune responses in broiler chicken reared in tropical summer. Biol. Trace Elem. Res. 2016. Vol. 172, No 1. P. 511-520.

32. Sevcikova S., Skrivan M., Dlouha G., Koucky M. The effect of selenium source on the performance and meat quality of broiler chickens. Czech. J. Anim. Sci. 2006. 51. P. 449-457.

33. Sharpe M., Perin I., Wrigglesworth J. Fatty acids as modulators of cytochrome $c$ oxidase in proteoliposomes. Biochem. J. 1996. Vol. 320, No 2. P. 557-561.

34. Skrivan M., Marounek M., Dlouha G., Sevcikova S. Dietary selenium increases vitamin E contents of egg yolk and chicken meat. Brit. Poultry Sci. 2008. 49. P. 482-486.

35. Skrivan M., Skrivanova V., Dlouha G., Branyikova I., Zachleder V., Vitova M. The use of selenium-enriched alga Scenedesmus quadricauda in chicken diet. Czech J. Anim. Sci. 2010. Vol. 55, No 12. P. 565-571.

36. Skulberg O. M. Bioactive chemicals in microalgae. In Handbook of Microalgal Culture: Biotechnology and Applied Phycology / ed. A. Richmond. Oxford : Blackwell Science, 2004. P. 485-512.

37. Straus W. Colometric microdetermination of cytochrome c oxidase. J. Biol. Chem. 1954. Vol. 207, No 2. P. 733-743.

38. Travnicek J., Racek J., Trefil L., Rodinova H., Kroupova V., Illek J., Doucha J., Pisek L. Activity of glutathione peroxidase (GSH-Px) in the blood of ewes and their lambs receiving the selenium-enriched unicellular alga Chlorella. Czech. J. Anim. Sci. 2008. 53. P. 292-298.

39. Vincent J. B. The Nutritional Biochemistry of Chromium (III). Tuscaloosa : Department of Chemistry the University of Alabama, USA, 2007. 277 p.

40. Yang J. S., Cao J., Xing L. G., Yuan H. Lipid production combined with biosorption and bioaccumulation of cadmium, copper, manganese and zinc by oleaginous microalgae Chlorella minutissima UTEX2341. Bioresour. Technol. 2015. 175. P. 537-544.

\section{O. I. Bodnar, H. B. Kovalska, O. Ya. Lukashiv, V. V. Grubinko}

Ternopil Volodymyr Hnatiuk National Pedagogical University, Ukraine

\section{EVALUATION OF THE BIOLOGICAL EFFECT OF ELEMENT-CONTAINING LIPID COMPLEXES FROM CHLORELLA VULGARIS ON THE FUNCTIONAL CONDITION OF RATS}

Chlorella is one of the most promising species of algae, which is widely cultivated for the industrial production of nutraceuticals in the form of tablets or powder. The value of Chlorella is primarily due to the high content of proteins and lipids (51-58 \% and 20-23\% of dry weight respectively), carotenoids and an almost complete set of vitamins. At the same time, in the process of cultivation, a method was developed to enrich algobiomass and its individual components (primarily the lipid fraction) with selenium, zinc, chromium, as important regulatory trace elements.

From chlorella, we obtained seleniumlipid, selenium-zinclipid and selenium-chromiumlipid complexes, and their constancy and structure were grounded by chromatographic and mass spectrometric analysis. After feeding healthy rats with a starch solution of selenium-zinclipid complex ( $1 \mathrm{ml}$ of which contained $0.4 \mu \mathrm{g}$ of selenium, $2.5 \mu \mathrm{g}$ of zinc and $0.5 \mathrm{mg}$ of lipids) and seleniumchromiumlipid complex ( $1 \mathrm{ml}$ contained $1.85 \mu \mathrm{g}$ of selenium, $1.1 \mu \mathrm{g}$ of chromium, $0,45 \mathrm{mg}$ of lipids), ISSN 2078-2357. Наук. зап. Терноп. нац. пед. ун-ту. Сер. Біол., 2020, № 3-4 (80) 
no signs of intoxication were found (total medium molecular peptides content was reduced to 1.5 times, the content of TBA-active products and diene conjugates were also decreased), antioxidant processes (increase of glutathione content and activity of glutathione peroxidase while reducing the functional role of catalase) were activated (by increasing of succinate dehydrogenase and cytochrome oxidase activity, glutamate dehydrogenase - the way of glutamate formation), which contributed to the successful functioning of the antioxidant system and maintenance of energy and metabolic homeostasis in the body.

The obtained results enable the use of biologically active additives from chlorella, enriched with trace elements $\mathrm{Se}$ (IV), $\mathrm{Zn}$ (II) and Cr (III), as promising therapeutic and prophylactic substances, which will contribute to the successful functioning of the antioxidant system, maintain energy metabolism and metabolism correction of pathological processes, which is the basis for further studies of the biological activity of the complexes under study.

Key words: Chlorella vulgaris, trace elements (Selenium, Zinc, Chromium), rats, metabolism, regulation.

Надійшла 23.10.2020.

УДК 597.551.2:632.95

doi: $10.25128 / 2078-2357.20 .3-4.8$

О. І. БОДНАР, С. В. СЕНЬКО, І. О. ОСИПЕНКО, І. ХАТІБ, Н. М. КАСЯНЧУК, Г. І. ФАЛЬФУШИНСЬКА

Тернопільський національний педагогічний університет імені Володимира Гнатюка вул. М. Кривоноса, 2, Тернопіль, 46027

e-mail: falfushynska@tnpu.edu.ua

\section{ВИВЧЕННЯ ЕФЕКТИВНОСТІ ХЛОРЕЛИ ЩОДО ЗМЕНШЕННЯ ЦИТОТОКСИЧНИХ ПРОЯВІВ У СМУГАСТОГО ДАНІО ЗА ВПЛИВУ ОРГАНОФОСФАТНИХ ПЕСТИЦИДІВ}

Екологічний потенціал мікроводоростей щодо очищення водних і грунтових екосистем та відновлення їх гомеостатичного функціонального стану природним шляхом вважається одним з найвищих завдяки швидкому росту й розвитку, лабільному й динамічному їх метаболізму та відносній невибагливості до умов зростання. Метою нашої роботи було дослідити ефективність хлорели як потенційного біоремедіатора для зменшення токсичного впливу пестицидів раундапу та хлорпірифосу за умов їх індивідуальної та комплексної дії на коропову рибу даніо Danio rerio. Вплив екологічно реальних концентрацій раундапу (15 мкг/л) та хлорпірифосу $(0,1$ мкг/л) викликав часткове виснаження пулу клітинних тіолів порівняно 3 контролем, яке проявлялося зменшенням загального вмісту глутатіону та глутатіонтрансферазної активності (за умов поєднаного впливу). Також встановлене зменшення рівня загальної антиоксидантної активності, яке узгоджувалося зі збільшенням рівня активних форм оксигену в тканині печінки. Водночас у даніо не проявлялися гострі ознаки нейротоксичності - активність ацетилхолінестерази збільшувалася та тлі відсутності візуальних проявів порушення рухових реакцій. До специфічних, залежних від природи пестициду, реакцій можна віднести збільшення концентрації метилгліоксалю та найбільш помітні ознаки ендокринних розладів за вмістом вітелогеніну за дії хлорпірифосу. Інтегральний аналіз даних методом головних компонент дозволив виявити окрему локалізацію кожної з досліджуваних груп та проміжне положення тварин за умов комбінованого впливу порівняно з їх індивідуальною дією. Внесення Chlorella vulgaris у кількості близько 100 тис. кл/дм ${ }^{3}$ у середовище не продемонструвало істотного коригуючого впливу на токсичність пестицидів для нетаргетного організму Danio rerio, що не виключає позитивного впливу водоростей на функціонування екосистеми загалом та потребує більш детального аналізу. 